\title{
PROTEKSI VAKSIN MONOVALEN DAN KOKTAIL SEL UTUH TERHADAP KO-INFEKSI Mycobacterium fortuitum DAN Aeromonas hydrophila PADA IKAN GURAME, Osphronemus gouramy
}

\author{
Uni Purwaningsih", Agustin Indrawati**), dan Angela Mariana Lusiastuti") \\ *) Balai Penelitian dan Pengembangan Budidaya Air Tawar \\ Jl. Sempur No. 1, Bogor 16151 \\ E-mail: uni_fish@yahoo.com \\ $\left.{ }^{* *}\right)$ Jurusan Mikrobiologi Medik, Fakultas Kedokteran Hewan Institut Pertanian Bogor \\ Jl. Agatis, Kampus IPB Dramaga, Bogor 16680
}

(Naskah diterima: 12 Desember 2013; Disetujui publikasi: 2 Mei 2014)

\begin{abstract}
ABSTRAK
Vaksinasi merupakan salah satu upaya aplikatif untuk melindungi ikan terhadap serangan agen patogen. Pemberian vaksin diharapkan dapat merangsang respons imun spesifik dan non spesifik pada ikan. Keberhasilan vaksinasi dipengaruhi oleh konsentrasi antigen, reaksi silang dan kompetisi di antara antigen yang berbeda. Penelitian ini bertujuan untuk menganalisis level proteksi vaksin monovalen dan koktail sel utuh terhadap ko-infeksi $M$. fortuitum dan A. hydrophila pada ikan gurame. Respons imun perlakuan vaksin monovalen maupun koktail pada gurame pasca ko-infeksi menunjukkan nilai parameter-parameter yaitu: hematokrit, hemoglobin, indeks fagositik, persentase fagositik, titer antibodi, uji respiratory burst (NBT), aktivitas komplemen, dan diferensial leukosit yang berbeda nyata $(P<0,05)$ dibanding kontrol. Vaksin monovalen A. hydrophila menunjukkan nilai RPS sebesar $92,3 \%$ dan monovalen $M$. fortuitum sebesar $78,6 \%$ setelah ditantang dengan infeksi tunggal bakteri homolog namun menunjukkan proteksi yang rendah terhadap ko-infeksi. Vaksin koktail 50Mf:50Ah memberikan proteksi yang lebih baik dari vaksin monovalen pasca uji tantang dengan ko-infeksi bakteri M. fortuitum dan A. hydrophila.
\end{abstract}

KATA KUNCl: M. fortuitum, A. hydrophila, vaksin monovalen, vaksin koktail, RPS, Osphronemus gouramy

ABSTRACT: The protection of whole cell monovalent and cocktail vaccine against co-infection $M$. fortuitum and A. hydrophila in gouramy (Osphronemus gouramy). By: Uni Purwaningsih, Agustin Indrawati, and Angela Mariana Lusiastuti

Vaccination was the one applicative effort to protect fish against pathogenic agents. The vaccination was expected to stimulate specific and non specific immune response in fish. The success of vaccination was influenced by the concentrations of antigens, cross-reactions, and competition among the different antigens. The aim of this study was to analyze the level protection of monovalent and cocktail vaccine against coinfection $\boldsymbol{M}$. fortuitum and $\boldsymbol{A}$. hydrophila in gouramy. The immune responses of monovalent and cocktail vaccine post co-infection showed the value of hematocrit, haemoglobin, phagocytic index, phagocytic percentage, antibody titers, respiratory burst test (NBT), complement activity, and differential leucocytes were significantly different $(P<0.05)$, compared to control. The relative percent survival (RPS) of mono- 
valent vaccine A. hydrophila showed RPS values $92.3 \%$ and $78.6 \%$ for monovalent $\boldsymbol{M}$. fortuitum after was challenged with a single infection bacterial homolog but showed a low protection against to co-infection. The cocktail vaccine with composition 50Mf: 50Ah provided better protection than the monovalent vaccine after challenge test with co-infection bacteria M. fortuitum and A. hydrophila.

\section{KEYWORDS: M. fortuitum, A. hydrophila, monovalent vaccine, cocktail vaccine} RPS, Osphronemus gouramy

\section{PENDAHULUAN}

Kasus kematian akibat infeksi bakteri Aeromonas hydrophila dan Mycobacterium fortuitum menjadi penghambat keberhasilan produksi budidaya ikan gurame. Kedua jenis penyakit tersebut mengakibatkan kerugian ekonomi dan menurunkan kualitas produk ikan gurame yang dihasilkan. Infeksi Mycobacteriosis dan Motile Aeromonas Septicemia (MAS) dilaporkan terjadi pada budidaya ikan gurame di sekitar daerah Parung, Bogor. Berdasarkan hasil uji identifikasi dan karakterisasi diperoleh dua jenis bakteri tersebut sebagai agen etiologinya. Oleh karena itu, perlu dicari solusi aplikatif untuk kedua jenis penyakit tersebut melalui pembekalan imun spesifik dengan pemberian vaksin koktail $M$. fortuitum dan $A$. hydrophila yang diharapkan dapat mencegah timbulnya infeksi kedua jenis penyakit tersebut pada budidaya gurame.

Vaksinasi merupakan upaya untuk meningkatkan respons imun terhadap patogen tertentu yang berdasarkan pada dua elemen imunitas adaptif yaitu spesifitas dan memori. Antigen yang digunakan sebagai vaksin dapat berupa organisme hidup yang masih ganas atau sudah dilemahkan, organisme utuh yang dimatikan, fragmen subseluler dan antigen permukaan sel, toksin yang diinaktifkan, rekombinan DNA dan anti-idiotipe.

Vaksin koktail adalah sediaan vaksin yang terdiri atas dua atau lebih antigen yang berasal dari jenis atau strain yang berbeda. Vaksin koktail yang efektif harus memenuhi tiga syarat utama yaitu: 1) mampu menginduksi imunitas yang tepat, 2) stabil dalam penyimpanan, dan 3) bersifat imunogenik. Menurut Baba et al. (1988), bahwa vaksinasi dengan larutan antigen ekstraselular lebih efektif dalam memberikan perlindungan melawan serotipe yang heterolog dibandingkan dengan vaksin yang hanya terdiri atas satu jenis sel utuh dari antigen.
Formula vaksin koktail ideal adalah dalam bentuk sediaan vaksin yang dapat memproteksi secara simultan terhadap beberapa patogen penting penyebab suatu penyakit dan efektif digunakan untuk spesies ikan yang luas. Vaksin koktail juga harus dapat melindungi dari semua serotipe bakteri yang berasal dari area geografis berbeda. Formula vaksin koktail harus dibuat dengan teliti karena masalah kompetisi antigen dapat muncul terutama ketika vaksin tersebut diaplikasikan melalui injeksi (Toranzo et al., 2009). Tingkat keberhasilan vaksinasi diukur dari nilai relative percent survival (RPS) dengan didukung parameter imunologi dan hematologi.

\section{BAHAN DAN METODE}

Preparasi vaksin koktail sel utuh dilakukan secara terpisah. Vaksin monovalen sel utuh $M$. fortuitum dibuat menurut metode Purwaningsih et al. (2012) dan monovalen sel utuh $A$. hydrophila menurut Sugiani et al. (2012).

Kajian efektivitas vaksin koktail terhadap pengaruh mono infeksi dan ko-infeksi $M$. fortuitum dan A. hydrophila dilakukan pada hari ke-21 pasca vaksinasi dengan menginjeksikan pada masing-masing perlakuan dengan mono infeksi M. fortuitum $10^{7} \mathrm{cfu}, A$. hydrophila $10^{8}$ cfu, dan infeksi gabungan keduanya (Tabel 1).

Pengamatan terhadap uji tantang dengan monovalen A. hydrophila dilakukan selama 14 hari sedangkan uji tantang dengan monovalen M. fortuitum dan ko-infeksi diamati selama 28 hari. Parameter uji yang diukur dalam tahap ini antara lain titer antibodi dengan menggunakan metode direct agglutination, aktivitas respiratory burst, komplemen menurut metode Vivas et al. (2005), patologi klinik darah (hematokrit menurut metode Anderson \& Siwicki, 1995), hemoglobin menurut metode Sahli (Wedenmeyer \& Yasutake, 1977), dan gambaran darah (diferensial leukosit, aktivitas fagositosis) dievaluasi menggunakan metode Zhang et al. (2008). 
Tabel 1. Perlakuan proteksi vaksin monovalen dan koktail M. fortuitum dan A. hydrophila

Table 1. The protection treatment of monovalent and cocktail vaccine from M. fortuitum and $\boldsymbol{A}$. hydrophila antigen

\begin{tabular}{|c|c|c|c|}
\hline $\begin{array}{l}\text { Perlakuan } \\
\text { Treatments }\end{array}$ & $\begin{array}{l}\text { Ulangan } \\
\text { Replication }\end{array}$ & $\begin{array}{l}\text { Komponen vaksin } \\
\text { Vaccine component }\end{array}$ & $\begin{array}{l}\text { Komponen uji tantang } \\
\text { Challenge test component }\end{array}$ \\
\hline \multirow{3}{*}{1} & 1 & 25 (su Mf) : 75 (su Ah) & M. fortuitum \\
\hline & 2 & 25 (su Mf) : 75 (su Ah) & A. hydrophila \\
\hline & 3 & 25 (su Mf) : 75 (su Ah) & Ko-infeksi (Co-infection) \\
\hline \multirow{3}{*}{2} & 1 & 50 (su Mf) : 50 (su Ah) & M. fort uitum \\
\hline & 2 & $50(\mathrm{su} \mathrm{Mf}): 50$ (su Ah) & A. hydrophila \\
\hline & 3 & $50(\mathrm{su} \mathrm{Mf}): 50$ (su Ah) & Ko-infeksi (Co-infection) \\
\hline \multirow{3}{*}{3} & 1 & 75 (su Mf) : 25 (su Ah) & M. fortuitum \\
\hline & 2 & 75 (su Mf) : 25 (su Ah) & A. hydrophila \\
\hline & 3 & 75 (su Mf) : 25 (su Ah) & Ko-infeksi (Co-infection) \\
\hline \multirow{3}{*}{4} & 1 & su Ah & M. fortuitum \\
\hline & 2 & su Ah & A. hydrophila \\
\hline & 3 & su Ah & Ko-infeksi (Co-infection) \\
\hline \multirow{3}{*}{5} & 1 & su Mf & M. fortuitum \\
\hline & 2 & su Mf & A. hydrophila \\
\hline & 3 & su Mf & Ko-infeksi (Co-infection) \\
\hline \multirow{3}{*}{6} & 1 & K & M. fortuitum \\
\hline & 2 & K & A. hydrophila \\
\hline & 3 & K & Ko-infeksi (Co-infection) \\
\hline
\end{tabular}

Keterangan (Note):

$\mathrm{Ah}=$ Aeromonas hydrophila, $\mathrm{Mf}=$ Mycobacterium fortuitum, $\mathrm{su}=\mathrm{Sel}$ utuh (Whole cell) $\mathrm{K}=$ Kontrol (Control)

\section{HASIL DAN BAHASAN}

Rata-rata kematian harian ikan gurame yang divaksin dengan vaksin monovalen $A$. hydrophila yang diuji tantang dengan bakteri A. hydrophila menunjukkan kematian yang lebih rendah sebesar 3,33\% dibanding perlakuan vaksin lain dan kontrol. Namun sebaliknya jika diuji tantang dengan $M$. fortuitum dan ko-infeksi $M$. fortuitum dan A. hydrophila menunjukkan tingkat kematian yang tinggi. Hal yang sama juga pada perlakuan vaksin monovalen $M$. fortuitum menunjukkan kematian yang rendah jika ditantang dengan bakteri $M$. fortuitum dan kumulatif kematian yang tinggi jika ditantang dengan bakteri $A$. hydrophila. Hal tersebut membuktikan bahwa vaksin monovalen hanya memberikan proteksi terhadap infeksi bakteri yang homolog dan tidak mem- berikan proteksi silang terhadap infeksi bakteri yang lain. Shieh (1987) mengungkapkan bahwa Atlantic salmon yang divaksinasi melalui injeksi intramuskular dengan vaksin sediaan ekstraselular protease dari $A$. hydrophila dapat melindungi dari uji tantang dengan bakteri yang homolog dan beberapa isolat bakteri yang heterolog dari A. hydrophila.

Berdasarkan analisis sidik ragam menunjukkan bahwa perlakuan vaksin monovalen A. hydrophila maupun $M$. fortuitum berbeda nyata $(P<0,05)$ dengan kontrol ketika diuji tantang dengan bakteri yang homolog. Kematian ikan akibat infeksi $A$. hydrophila mulai terjadi pada hari ke-2 sampai hari ke-14, di mana rata-rata kematian tertinggi terjadi pada hari ke-4 sampai hari ke-7 (Gambar 1). Kematian ikan akibat infeksi $M$. fortuitum terjadi pada hari 
ke-11-28, jumlah kematian tertinggi mulai terjadi pada hari ke-21-25 (Gambar 2). Pola infeksi kedua jenis bakteri tersebut berbeda, A. hydrophila menyebabkan infeksi akut sedangkan $M$. fortuitum menyebabkan infeksi yang bersifat kronis. A. hydrophila pada kondisi optimum hanya membutuhkan waktu dalam hitungan jam untuk menyebabkan infeksi pada inang berbeda halnya dengan $M$. fortuitum yang membutuhkan waktu lebih lama.

Kematian ikan gurame setelah diuji tantang dengan ko-infeksi $M$. fortuitum dan $A$. hydrophila terjadi pada hari ke- 15 sampai hari ke-28, dengan jumlah kematian tertinggi terjadi pada hari ke-22 sampai hari ke-25 (Gambar 3). Perlakuan vaksin monovalen $A$. hydrophila dan M. fortuitum menunjukkan kematian yang lebih tinggi daripada perlakuan vaksin koktail $M$. fortuitum dan A. hydrophila. Kondisi demikian menunjukkan bahwa vaksin koktail mampu memberikan proteksi silang lebih baik dibanding vaksin monovalen terhadap ko-infeksi $M$. fortuitum dan $A$. hydrophila. Vaksin koktail dengan komposisi $50 \%$ M. fortuitum dan $50 \%$ A. hydrophila mampu memberikan proteksi terbaik terhadap uji tantang bakteri $A$. hydrophila, M. fortuitum, dan ko-infeksi keduanya.
Vaksinasi merupakan salah satu upaya untuk melindungi tubuh ikan terhadap infeksi patogen tertentu. Pemberian vaksin diharapkan dapat merangsang respons imun spesifik dan non spesifik pada ikan. Keberhasilan vaksinasi pada ikan dapat dilihat dari beberapa parameter pendukung antara lain: hematokrit, hemoglobin, indeks fagositik, persentase fagositik, titer antibodi, uji respiratory burst (NBT), aktivitas komplemen, dan diferensial leukosit. Perubahan parameter pendukung efikasi vaksin monovalen dan koktail $M$. fortuitum dan $A$. hydrophila setelah diuji tantang dengan bakteri $A$. hydrophila, $M$. fortuitum, dan gabungan keduanya dapat dilihat selengkapnya pada Tabel 2, 3, dan 4.

Ada korelasi yang kuat antara hematokrit dan jumlah hemoglobin, semakin rendah jumlah sel-sel darah merah maka semakin rendah pula kandungan hemoglobin dalam darah (Fujaya, 2004). Kadar hematokrit dan hemoglobin pada ikan gurame perlakuan vaksin monovalen dan koktail $M$. fortuitum dan $A$. hydrophila setelah diuji tantang dengan bakteri $A$. hydrophila, M. fortuitum, dan gabungan keduanya menunjukkan nilai lebih tinggi dan berbeda nyata $(P<0,05)$ dibanding dengan kontrol (Tabel 2, 3, dan 4), artinya

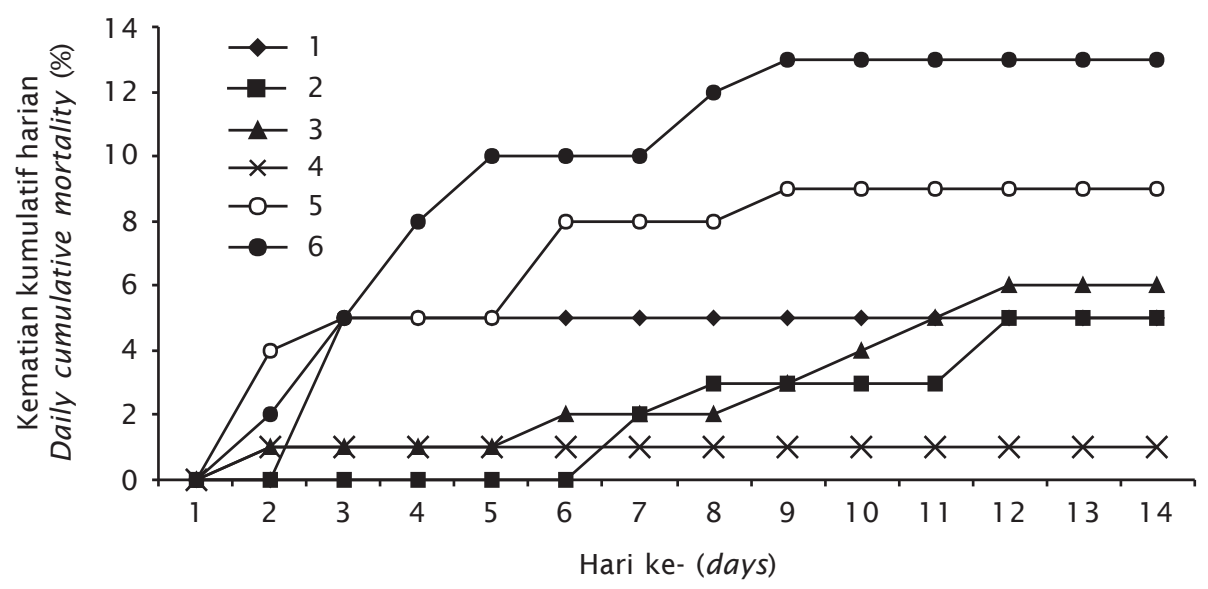

Gambar 1. Kematian kumulatif harian ikan gurame yang divaksinasi dengan vaksin monovalen dan koktail yang diinaktifasi dengan buffer formalin 3\% setelah diuji tantang dengan bakteri $A$. hydrophila. (1-6 adalah perlakuan, 1. Koktail $25 \mathrm{Mf}+75 \mathrm{Ah}, 2$. Koktail $50 \mathrm{Mf}+50 \mathrm{Ah}, 3$. Koktail $75 \mathrm{Mf}+25 \mathrm{Ah}, 4$. Monovalen A. hydrophila, 5. Monovalen M. fortuitum, 6. Kontrol)

Figure 1. Daily cumulative mortality of gouramy vaccinated with monovalent and cocktail vaccine that inactivated with $3 \%$ buffer formalin after challenge with bacteria A. hydrophila. (1-6 were the treatment, 1. Cocktail $25 \mathrm{Mf}+75 \mathrm{Ah}$, 2. Cocktail $50 \mathrm{Mf}+50 \mathrm{Ah}$, 3. Cocktail 75Mf $+25 \mathrm{Ah}$, 4. Monovalent A. hydrophila, 5. Monovalent M. fortuitum, 6. Control) 


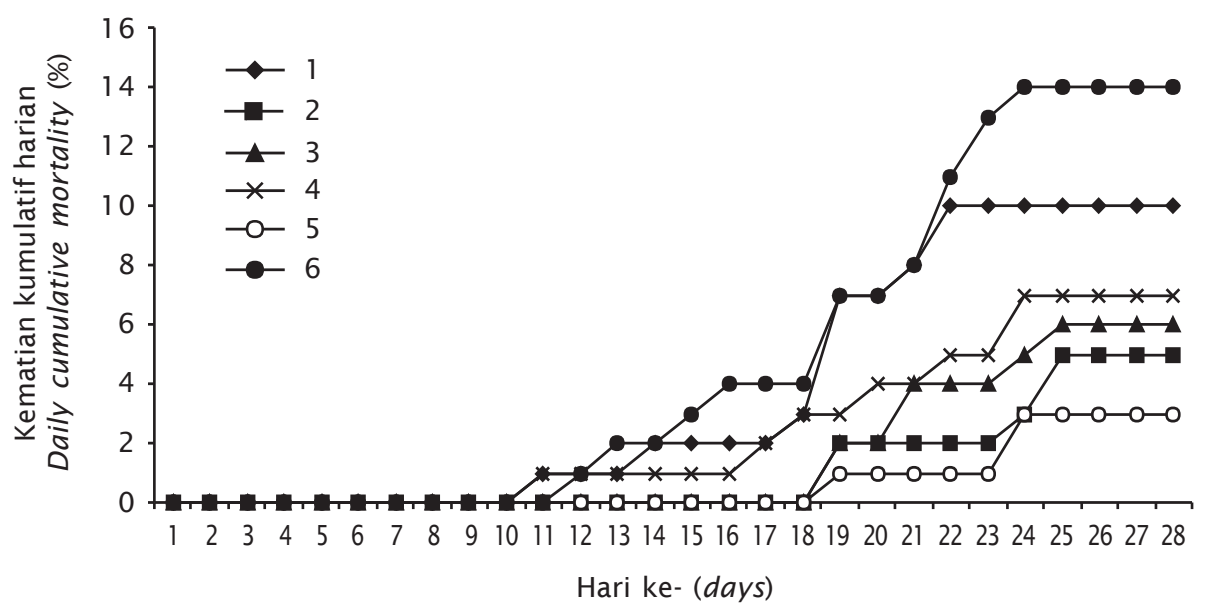

Gambar 2. Kematian kumulatif harian ikan gurame yang divaksinasi dengan vaksin monovalen dan koktail yang diinaktifasi dengan buffer formalin $3 \%$ setelah diuji tantang dengan bakteri M. fortuitum. (1-6 adalah perlakuan, 1. Koktail 25 $\mathrm{Mf}+75$ Ah, 2. Koktail $50 \mathrm{Mf}+50 \mathrm{Ah}, 3$. Koktail 75 Mf +25 Ah, 4. Monovalen A. hydrophila, 5. Monovalen M. fortuitum, 6. Kontrol)

Figure 2. Daily cumulative mortality of gouramy vaccinated with monovalent and cocktail vaccine that inactivated with $3 \%$ buffer formalin after challenge with bacteria M. fortuitum. (1-6 were the treatment, 1. Cocktail $25 \mathrm{Mf}+75 \mathrm{Ah}$, 2. Cocktail $50 \mathrm{Mf}+50 \mathrm{Ah}$, 3. Cocktail 75Mf $+25 \mathrm{Ah}$, 4. Monovalent A. hydrophila, 5. Monovalent M. fortuitum, 6. Control)

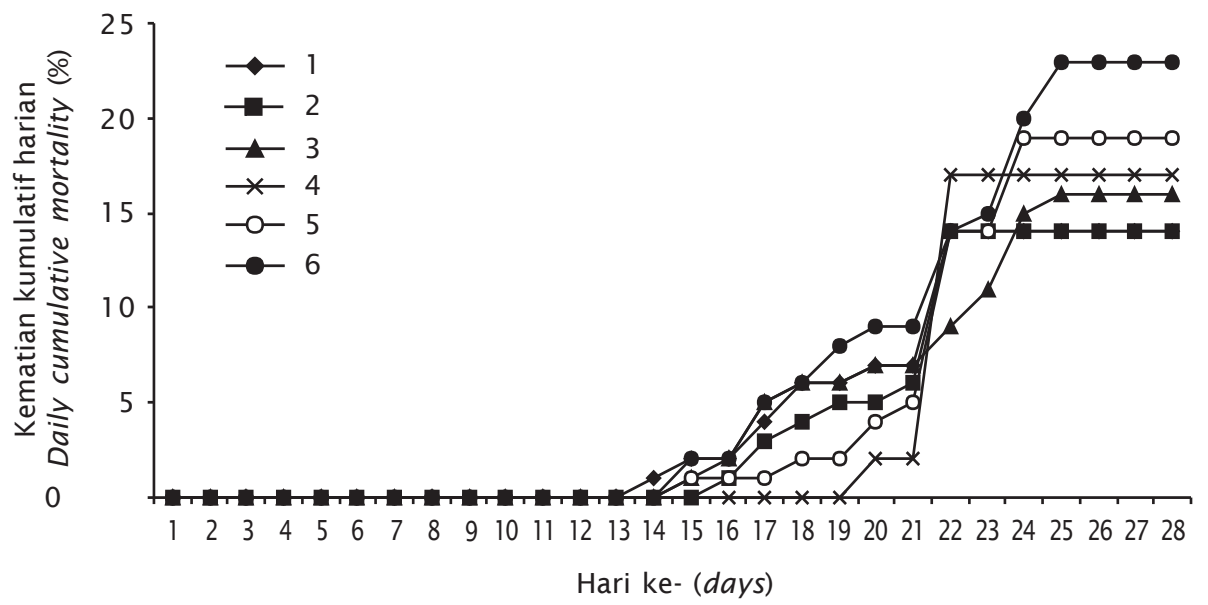

Gambar 3. Kematian kumulatif harian ikan gurame yang divaksinasi dengan vaksin monovalen dan koktail yang diinaktifasi dengan buffer formalin 3\% setelah diuji tantang dengan ko-infeksi bakteri M. fortuitum dan A. hydrophila. (1-6 adalah perlakuan, 1. Koktail $25 \mathrm{Mf}+75 \mathrm{Ah}, 2$. Koktail $50 \mathrm{Mf}+50 \mathrm{Ah}, 3$. Koktail $75 \mathrm{Mf}$ + 25 Ah, 4. Monovalen A. hydrophila, 5. Monovalen M. fortuitum, 6. Kontrol)

Figure 3. Daily cumulative mortality of gouramy vaccinated with monovalent and cocktail vaccine that inactivated with $3 \%$ buffer formalin after challenge with co-infection bacteria M. fortuitum and A. hydrophila. (1-6 were the treatment, 1. Cocktail $25 \mathrm{Mf}+75 \mathrm{Ah}, 2$. Cocktail $50 \mathrm{Mf}+50 \mathrm{Ah}$, 3. Cocktail 75Mf+ 25 Ah, 4. Monovalent A. hydrophila, 5. Monovalent M. fortuitum, 6. Control) 


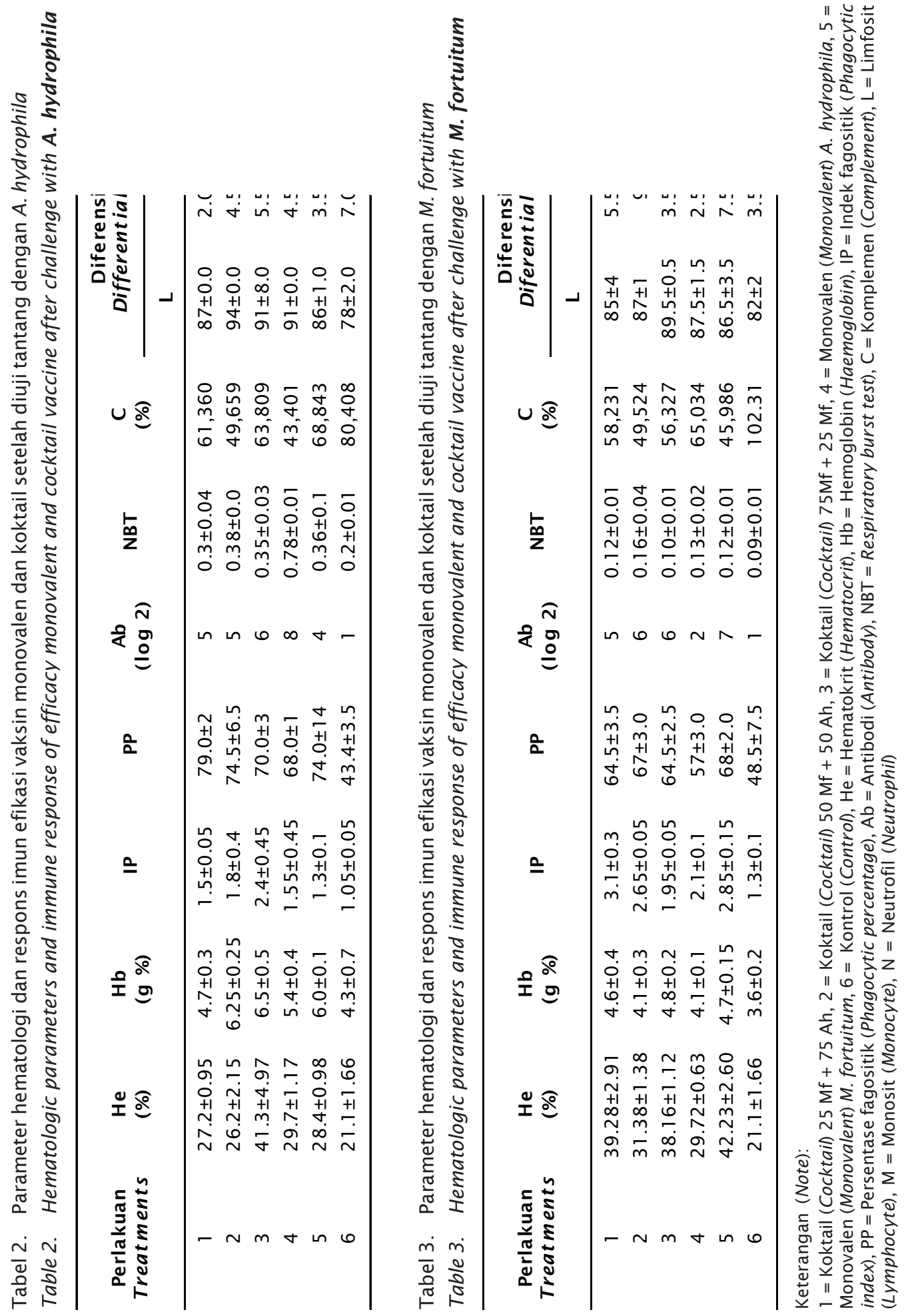




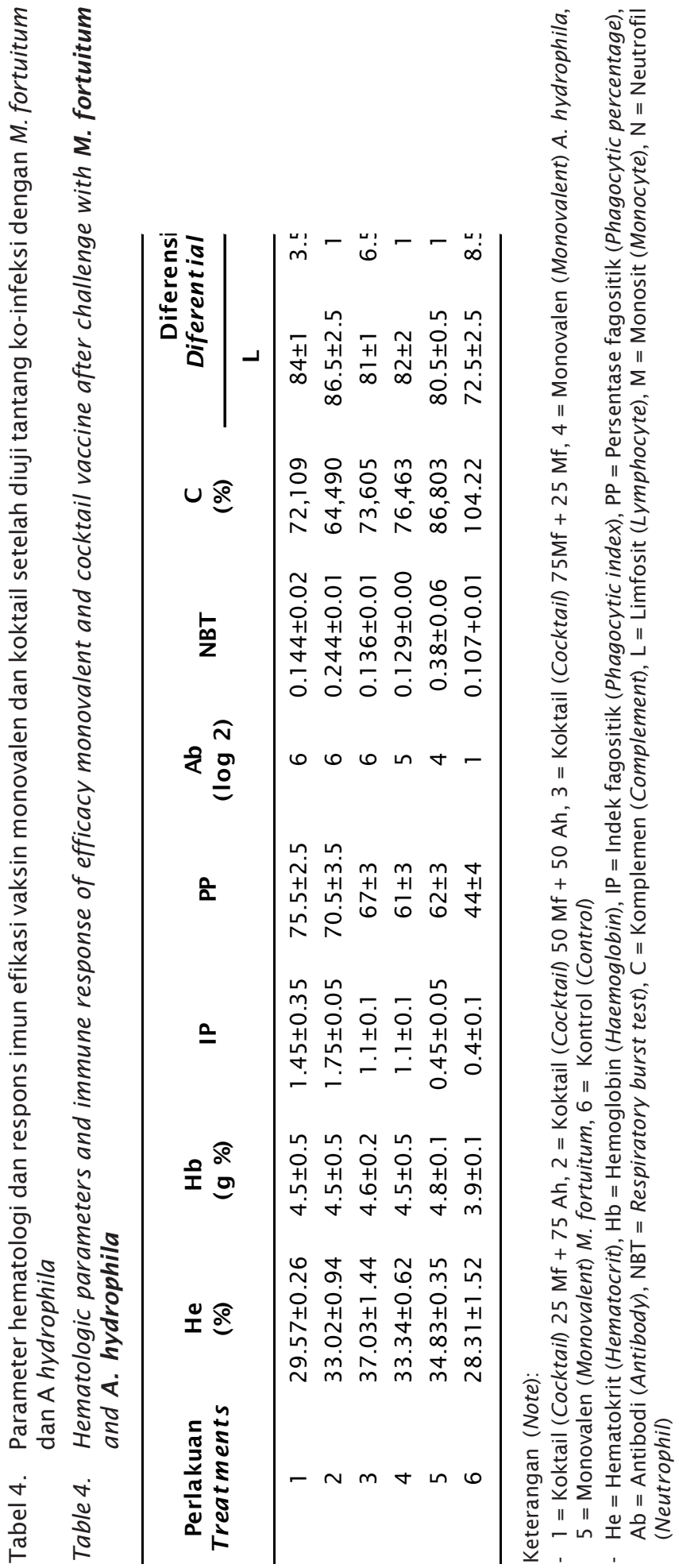


vaksin yang diberikan mampu membantu tubuh ikan untuk mempertahankan diri dan mencegah berkembangnya patogen dalam tubuh sehingga tidak menyebabkan sakit. Infeksi $M$. fortuitum dan A. hydrophila tidak berpengaruh nyata terhadap kadar hematokrit dan hemoglobin pada perlakuan vaksin sehingga tidak mengakibatkan gangguan keseimbangan tubuh ikan.

Kemampuan fagositosis pada ikan gurame yang divaksin dengan vaksin monovalen dan koktail M. fortuitum dan A. hydrophila setelah diuji tantang dengan bakteri $A$. hydrophila, $M$. fortuitum, dan gabungan keduanya menunjukkan berbeda nyata $(\mathrm{P}<0,05)$ dibandingkan kontrol (Tabel 2, 3, dan 4). Aktivitas fagositosis yang tinggi mengindikasikan vaksin mampu meningkatkan komponen respons imun non spesifik pada ikan sehingga mampu menghancurkan bakteri yang masuk sebagai benda asing ke dalam tubuh ikan.

Respons imun spesifik ikan diekspresikan dengan adanya aglutinasi terhadap antigen dan presipitasi terhadap antigen terlarut (Nitimulyo \& Triyanto, 1990). Pemberian vaksin pada ikan menstimulasi terbentuknya antibodi dalam jumlah banyak yang teridentifikasi dengan terjadinya penggumpalan yang dikenal dengan titer antibodi. Titer antibodi ikan gurame yang divaksin dengan vaksin monovalen dan koktail menunjukkan nilai titer antibodi log 2 yang berbeda nyata $(P<0,05)$ dibandingkan dengan kontrol setelah ditantang dengan bakteri $A$. hydrophila, $M$. fortuitum, dan gabungan keduanya (Tabel 2 , 3, dan 4). Pada perlakuan vaksin monovalen menunjukkan nilai titer yang lebih tinggi daripada vaksin koktail dan kontrol setelah ditantang dengan bakteri homolog, namun sebaliknya jika ditantang dengan bakteri yang tidak homolog menunjukkan nilai titer yang lebih rendah. Imunoglobulin pada ikan hanya menyerupai IgM (IgM like) sehingga pembentukan antibodi pascavaksinasi pada ikan tidak seoptimal pada hewan tingkat tinggi.

Perubahan dalam kadar komplemen menunjukkan adanya proses penyakit. Pada saat antibodi tersangkut pada permukaan mikroorganisme yang menyerang, serangkaian protein plasma yang disebut komplemen akan teraktivasi. Protein komplemen ini mampu menghancurkan penyerang tersebut. Proses ini dimulai oleh perubahan konformasional pada daerah Fc, bagian antibodi yang berikatan dengan antigen. Jika antigen tersebut me- layang bebas dalam sirkulasi sebagai molekul tunggal, kompleks imun yang terbentuk dapat berikatan pula dengan komplemen. Komplemen dalam kompleks tersebut kemudian dapat membantu menarik sel-sel fagosit, yang akan menelan dan membuang antigen yang diinaktivasi dari sirkulasi. Menurut Sugiani et al. (2012), bahwa pemberian vaksin monovalen dan koktail dapat memengaruhi respons imun, diduga dengan adanya antibodi akan menginisiasi aksi berantai komplemen sehingga lisozim serum dapat masuk ke dalam lapisan peptidoglikan bakteri dan menyebabkan kematian sel.

Indikator respons imun non spesifik juga dapat dilihat dari proporsi komponen sel darah putih yaitu limfosit, monosit, dan neutrofil. Limfosit tidak bersifat fagositik namun memegang peranan penting dalam pembentukan antibodi. Kekurangan jumlah limfosit dapat menurunkan konsentrasi antibodi dan menyebabkan meningkatnya serangan penyakit. Persentase total limfosit pada perlakuan vaksin monovalen maupun koktail pasca uji tantang dengan bakteri $A$. hydrophila, M. fortuitum, dan ko-infeksi keduanya menunjukkan nilai yang berbeda nyata $(P<0,05)$ dengan kontrol (Tabel 2, 3, dan 4). Hal tersebut menandakan bahwa pemberian vaksin monovalen dan koktail dapat meningkatkan jumlah limfosit untuk menghasilkan antibodi.

Neutrofil berperan pada aktivitas fagositik dan sitotoksik, bermigrasi ke tempat inflamasi dan infeksi atas pengaruh faktor kemotaktik. Peran utama neutrofil adalah sebagai pertahanan awal imun non spesifik terhadap infeksi bakteri. M. fortuitum dan A. hydrophila adalah tipe bakteri yang menghasilkan produk ekstraselular, di mana toksin yang dihasilkan akan dinetralkan dan bakteri yang masuk akan dieliminasi oleh sel fagosit yaitu neutrofil, monosit, dan makrofag. Faktor virulensi $A$. hydrophila melibatkan adhesi (misalnya pilus), lapisan protein permukaan (S layer), dan beberapa enzim ekstra seluler termasuk protease, haemolysin, enterotoksin, serta acetycholinesterase (Liu \& Bi, 2007). Lipopolisakarida dalam dinding bakteri $A$. hydrophila dapat mengaktivasi komplemen jalur alternatif tanpa adanya antibodi. Hasil aktifasi ini adalah komplemen (C3b) yang mempunyai efek opsonisasi, lisis bakteri melalui serangan kompleks membran dan respons inflamasi akibat pengumpulan, serta aktifasi leukosit. Endotoksin juga merangsang 
makrofag dan sel lain seperti endotel vaskular untuk memproduksi sitokin seperti interleukin (IL-1, IL-6, dan IL-8). Dinding bakteri M. fortuitum mengandung suatu komponen lipid yang dapat menghambat pengabungan fagosom dengan lisosom sehingga menyebabkan respons imun terhadap infeksi dan pembentukan respons imun spesifik yang diperantarai selsel limfosit juga menjadi terhambat. Perbedaan dalam dinding sel strain mikobakteri bisa menjadi alasan untuk memicu sitokin yang berbeda terhadap respons inflamasi yang berbeda. Beberapa sitokin (seperti interleuken-4, IL-4 dan interferon-g, IFN-g) menginduksi pembentukan sel raksasa dari monosit darah/ makrofag. Dengan bantuan ofeither IL-3 atau granulosit-makrofag colony-stimulating factor (GM-CSF), IL-4 menginduksi sel raksasa yang sangat besar sampai dengan 285 inti, sedangkan IFN-g cenderung menginduksi sel raksasa yang relatif kecil (misalnya 16 inti per sel) (Talaat et al., 1999).

Nilai RPS perlakuan vaksin monovalen dan koktail setelah diuji tantang dengan infeksi tunggal maupun ko-infeksi terlihat pada Tabel 5. Vaksin monovalen $A$. hydrophila menunjukkan nilai RPS sebesar 92,3\% berbeda nyata dengan perlakuan vaksin lain $(P<0,05)$ setelah uji tantang dengan bakteri $A$. hydrophila dan nilai RPS $42,86 \%$ setelah diuji tantang dengan M. fortuitum. Vaksin monovalen M. fortuitum menunjukkan nilai RPS $78,57 \%$ berbeda nyata
$(P<0,05)$ dari perlakuan vaksin lain setelah ditantang dengan $M$. fortuitum. Vaksin koktail 25 Mf:75 Ah menunjukkan nilai RPS yang rendah dan berbeda nyata $(P<0,05)$ dengan perlakuan vaksin lain setelah diuji tantang dengan M. fortuitum, hal ini diduga disebabkan jumlah antibodi terhadap M. fortuitum yang terbentuk tidak cukup untuk mengantisipasi infeksi M. fortuitum. Berdasarkan hasil tersebut menunjukkan vaksin monovalen efektif memberikan proteksi terhadap mono infeksi bakteri homolog dan proteksi silang yang sangat rendah terhadap bakteri lain dan ko-infeksi. Suatu vaksin dikatakan efektif apabila nilai RPS $850 \%$, tingkat kematian pada kontrol paling sedikit $60 \%$, sedangkan tingkat kematian pada ikan yang divaksin kurang dari 24\% (Ellis, 1988).

Antigen vaksin monovalen dan koktail mengandung material protein yang bersifat imunogenik dengan ukuran 61-108 kDa, yang sesuai dengan pernyataan Stuart (1999) molekul antigen yang bersifat imunogenik memiliki ukuran lebih besar dari $60 \mathrm{kDa}$. Nilai RPS perlakuan vaksin koktail menunjukkan nilai yang rendah setelah diuji tantang dengan ko-infeksi, hal tersebut mengindikasikan vaksin tidak memberikan level proteksi yang optimum jika terjadi infeksi $M$. fortuitum dan $A$. hydrophila dalam waktu yang bersamaan.

Efikasi vaksin secara injeksi intraperitoneal memberikan hasil yang lebih baik dalam mem-

Tabel 5 Tingkat RPS ikan gurame yang divaksinasi dengan vaksin monovalen dan koktail $M$. fortuitum dan A. hydrophila

Table 5. Relative percent survival (RPS) levels of gouramy vaccinated with monovalent and cocktail vaccines of $M$. fortuitum and A. hydrophila

\begin{tabular}{cccc}
\hline \multirow{2}{*}{$\begin{array}{c}\text { Perlakuan } \\
\text { Treatments }\end{array}$} & \multicolumn{2}{c}{ Relative percent survival (RPS) setelah diuji tant ang (after challenge) } \\
\cline { 2 - 4 } & A. hydrophila & M. fort uit um & $\begin{array}{c}\text { Ko-infeksi (Co-infection) M. fort uit um } \\
\text { dan (and) A. hydrophila }\end{array}$ \\
\hline 1 & $61.5347^{\mathrm{b}}$ & $28.5714286^{\mathrm{c}}$ & $39.1307^{\mathrm{a}}$ \\
2 & $61.5278^{\mathrm{b}}$ & $57.1428571^{\mathrm{b}}$ & $39.1303^{\mathrm{a}}$ \\
3 & $53.8426^{\mathrm{b}}$ & $57.1428571^{\mathrm{b}}$ & $30.4351^{\mathrm{b}}$ \\
4 & $92.3148^{\mathrm{a}}$ & $42.8571429^{\mathrm{b}}$ & $26.0873^{\mathrm{b}}$ \\
5 & $30.7600^{\mathrm{c}}$ & $78.5714286^{\mathrm{a}}$ & $17.3917^{\mathrm{c}}$ \\
\hline
\end{tabular}

Keterangan (Note):

- 1 = Koktail (Cocktail) 25 Mf + 75 Ah, 2 = Koktail (Cocktail) 50 Mf + 50 Ah, $3=$ Koktail (Cocktail) $75 \mathrm{Mf}+25$ Mf, 4 = Monovalen (Monovalent) A. hydrophila, 5 = Monovalen (Monovalent) M. fortuitum

- Angka yang diikuti oleh huruf yang sama pada kolom yang sama menunjukkan tidak berbeda nyata $(\mathrm{P}>0,05)$ (Number in the same colomn and row followed by the same superscript are not significant different $(P>0.05))$ 
bentuk respons humoral antibodi dibanding dengan pemberian vaksin melalui rendam atau semprot (Thune \& Plumb, 1982). Keberhasilan vaksin koktail dipengaruhi oleh konsentrasi antigen, reaksi silang dan kompetisi di antara antigen yang berbeda. Penelitian yang dilakukan oleh Nikoslelainen et al. (2007) menunjukkan bahwa vaksin koktail sel utuh memberikan proteksi yang lebih baik daripada vaksin monovalen pada ikan rainbow trout dan salmon Atlantik (Salmo salar). Bastardo et al. (2012) mengemukakan vaksin koktail $L$. garvieae dan $A$. hydrophila memberikan level proteksi sebesar $76,5 \%$ setelah ditantang dengan L. garvieae dan $85 \%$ setelah ditantang dengan A. hydrophila dan terhadap gabungan infeksi keduanya sebesar $70 \%$. Perlakuan vaksin koktail dalam penelitian ini memberikan level proteksi terhadap mono infeksi bakteri $A$. hydrophila dengan tingkat sintasan sebesar 80\%-83,33\% atau $M$. fortuitum dengan tingkat sintasan sebesar $66,67 \%-80 \%$ namun tidak memberikan proteksi yang optimum terhadap ko-infeksi M. fortuitum dan A. hydrophila. Vaksin monovalen $A$. hydrophila dan $M$. fortuitum memberikan proteksi terhadap infeksi bakteri homolog dan tidak memberikan proteksi silang terhadap jenis yang berbeda. Hal tersebut diduga disebabkan oleh faktor kurangnya kompetisi antigenik antara patogen bakteri tahan asam dan gram-negatif.

Menurut Tommaso et al. (1994), penggunaan formaldehid sebagai bahan inaktifasi dalam preparasi vaksin monovalen dan koktail terbukti mampu meningkatkan proteksi respons antibodi, akan tetapi formaldehid juga dapat berpengaruh terhadap pengenalan antigen oleh sel-T. Pengenalan sel-T terhadap antigen sebagai ikatan peptida akan membentuk molekul major hystocompability complex (MHC), formaldehid dapat memengaruhi presentasi antigen dengan cara interfensi pada saat degradasi proteolitik menjadi peptida membentuk ikatan peptida jadi MHC atau pengenalan reseptor sel-T terhadap peptidaMHC kompleks.

Faktor pendukung keberhasilan efikasi selama masa induksi dan setelah uji tantang dipengaruhi oleh kondisi lingkungan perairan yang sesuai untuk pertumbuhan ikan gurame. Nilai kualitas air selama penelitian disajikan pada Tabel 6.

Berdasarkan hasil pengamatan terhadap kualitas air media pemeliharaan ikan uji menunjukkan bahwa kisaran kualitas air media pemeliharaan dari empat parameter yaitu: suhu, pH, DO, dan TAN tersebut sesuai untuk pemeliharaan ikan uji yaitu gurame. Hal ini menunjukkan bahwa hasil penelitian yang diperoleh disebabkan adanya perbedaan perlakuan dan bukan merupakan pengaruh dari kualitas air.

\section{KESIMPULAN DAN SARAN}

\section{Kesimpulan}

Vaksin monovalen dan koktail sel utuh $M$. fortuitum dan A. hydrophila dapat meningkatkan respons imun spesifik dan non spesifik pada gurame. Level proteksi vaksin monovalen sel utuh lebih baik dibanding vaksin koktail sel utuh terhadap infeksi tunggal bakteri homolog, namun sebaliknya jika ditantang dengan ko-infeksi vaksin koktail menunjukkan level proteksi yang lebih tinggi dibanding vaksin monovalen. Sediaan vaksin koktail sel utuh dengan komposisi 50Mf : 50Ah mampu menginduksi respons imun spesifik dan non spesifik terbaik terhadap koinfeksi daripada vaksin monovalen pada ikan gurame

\section{Saran}

Penelitian lanjutan perlu dilakukan untuk mendapatkan komposisi optimal dari sediaan vaksin koktail M. fortuitum dan A. hydrophila

Tabel 6. Kisaran hasil pengukuran kualitas air selama penelitian

Table 6. The water quality measurement during the study

\begin{tabular}{lc}
\hline \multicolumn{1}{c}{$\begin{array}{c}\text { Parameter } \\
\text { Parameters }\end{array}$} & $\begin{array}{c}\text { Kisaran } \\
\text { Range }\end{array}$ \\
\hline Suhu (Temperature) $\left({ }^{\circ} \mathrm{C}\right)$ & $30-32$ \\
$\mathrm{pH}$ & $6.5-7.0$ \\
TAN (Totally of ammonium and nitrogen $)(\mathrm{mg} / \mathrm{L})$ & $0.014-0.106$ \\
Oksigen terlarut (Dissolved oxygen) $(\mathrm{mg} / \mathrm{L})$ & $5-8$ \\
\hline
\end{tabular}


yang memiliki level proteksi tinggi terhadap ko-infeksi penyakit Mycobacteriosis dan MAS dengan mempertimbangkan aspek karakteristik antigen, reaksi silang, dan immunokompetisi antigen pada ikan gurame.

\section{UCAPAN TERIMA KASIH}

Penelitian ini dapat terlaksana dengan baik berkat dukungan Balai Penelitian dan Pengembangan Budidaya Air Tawar, Bogor. Penghargaan yang tinggi penulis sampaikan kepada Dr. Desy Sugiani, M.Si., Ir. Taukhid, M.Sc., Saudara Ahmad Wahyudi, Edy Farid Wadjdy, dan staf laboratorium mikrobiologi FKH IPB yang telah banyak membantu dalam penelitian ini.

\section{DAFTAR ACUAN}

Anderson, D.P. \& Siwicki, A.K. 1995. Basic hematology and serology for fish health programs. In Shariff, M., Arthur, J.R., Subasinghe, R.P., (Eds.), Fish Health Section. Asia Fisheries Society (Eds.), Disease in Asian Aquaculture II. Manila. Philippines, p. 185-202.

Baba, T., Imamura, J., Izawa, K., \& Ikeda, K. 1988. Immune protection in carp, Cyprinus carpio L., after immunization with Aeromonas hydrophila crude lipopolysaccharide. Journal of Fish Diseases, 11 : 237-244.

Bastardo, A., Ravelo, C., Castro, N., Calheiros, J., \& Romalde, J.L. 2012. Effectiveness of bivalent vaccines against $A$. hydrophila and Lactococcus garvieae infections in rainbow trout, Oncorhynchus mykiss (walbaum). Journal Fish \& Shellfish Immunology, 32: 756-761.

Ellis, A.E. 1988. General principles of fish vaccination. In Ellis, A.E. (Ed.), Fish vaccination. Academic Press. London, p. 1-19.

Fujaya, Y. 2004. Fisiologi ikan: Dasar pengembangan teknik perikanan. Rineka Cipta. Jakarta, p. 95-99.

Liu, Y. \& Bi, Z. 2007. Potential use of a transposom Tn916-generated mutant of Aeromonas hydrophila J-1 defective in some exoproducts as a live attenuated vaccine. Journal of Veterinary Medicine, 78 : 79-84.

Nikoskelainen, S., Verho, S., Jarvinen, S., Madetoja, J., Wiklund, T., \& Lilius, E.M. 2007. Multiple whole bacterial antigens in polyvalent vaccine may result in inhibition of specific responsses in rainbow trout (Oncorhynchus mykiss). Fish and Shellfish Immunology, 22: 206-217.
Nitimulyo, K.H. \& Triyanto. 1990. Vaksinasi Monovalen dan Polivalen Vaksin untuk Mengatasi Serangan Aeromonas hydrophila pada Ikan Lele (Clarias sp.). Jurnal Ilmu Pertanian (Agricultural Science), 4: 447464.

Purwaningsih, U., Lusiastuti, A.M., \& Taukhid. 2012. Pengembangan berbagai jenis sediaan vaksin $M$. fortuitum untuk mencegah penyakit mycobacteriosis pada gurame (Osphronemus gouramy). Seminar Hasil Riset 2012. Balai Penelitian dan Pengembangan Budidaya Air Tawar. Unpublised.

Shieh, H.S. 1987. Protection of Atlantic salmon against motile aeromonad septicaemia with Aeromonas hydrophila protease. Microbios Letters, 36: 133-138.

Stuart, M. 1999. Immunology spring 1999. Department of Mycrobiology/Immunology. Kirkville College of Osteopathic Medicine. http://www.kcom.cdu/faculty/chamberlain/msimn (diakses 2 Juni 2013).

Sugiani, D. \& Lusiastuti, A.M. 2011 . Kerentanan ikan tilapia (Oreochromis niloticus) terhadap serangan ko-infeksi Streptococcosis dan MAS. Prosiding Seminar Nasional Tahun VIII Hasil Penelitian Perikanan dan Kelautan Jurusan Perikanan dan Kelautan UGM. Yogyakarta, 16 Juli 2011.

Sugiani, D. 2012. Vaksin bivalen untuk pencegahan penyakit Motile Aeromonas Septicemia dan Streptococcosis pada ikan nila (Oreochromis niloticus) [Disertasi]. Bogor. Sekolah Pascasarjana, Institut Pertanian Bogor.

Talaat, A.M., Trucksis, M., Kane, A.S., \& Reimshuessel, R. 1999. Pathogenicity of Mycobacterium fortuitum and Mycobacterium smegmatis to goldfish, Carrasius auratus. Journal of Veterinary Microbiologi, 66: 151-164.

Thune, R.L. \& Plumb, J.A. 1982. Effect of delivery method and antigen preparation on the production of antibodies against Aeromonas hydrophila in channel catfish. Progressive Fish-Culturist, 44: 53-54.

Tommaso, A.D., Magistris, M.T., Bugnoli, M., Marsili, I., Rappuoli, R., Abrignani, S. 1994. Formaldehyde treatment of proteins can constrain presentation to $T$ cells by limiting antigen processing. Infection and Immunity, 62(5): 1,830-1,834.

Toranzo, A.E., Romalde, J.L., Magarinos, B., \& Barja, J.L. 2009. Present and future of aquaculture vaccines against fish bacterial dis- 
eases. The use of veterinary drugs and vaccines in Mediterranean aquaculture. Options Mediterraneennes A., 86: 155-176.

Vivas, J., Razquin, B., Lopez-Fierro, P., \& Villena, A.J. 2005. Modulation of the immune response to an Aeromonas hydrophila aro A live vaccine in rainbow trout: effect of culture media on the humoral immune response and complement consumption. Fish and Shellfish Immunology, 18: 223-233.

Wedenmeyer, G.A. \& Yasutake, W.T. 1977. Clinical methods for the assessment of the ef- fect on environmental stress on fish health. Technical Papers of the US. Fish and Wildlife Service. US Depart. of the Interior. Fish and Wildlife Service, 89: 1-17.

Zhang, J., Zou, W., \& Yan, Q. 2008. Non-specific immune response of bullfrog Rana catesbeiana to intraperitoneal injection of bacterium Aeromonas hydrophila. Chinesse Journal of Oceanology and Limnology, 26(3): 248-255. 